\title{
KAN EN KVINNE BLI AYATOLLAH?
}

I Iran står kvinner med teologisk utdannelse $i$ en særegen posisjon når det argumenteres for nytolkninger av shari' a. Et av de store Kathrine Pettersen var i Iran høsten 2000 i forbindelse med hovedfaget. Hun arbeider i dag som universitetslektor i religionshistorie ved stridspørsmålene er hvorvidt islam tillater kvinnelige ayatollaher. Institutt for kulturstudier, UiO. 
TEKST: Kathrine Pettersen

SELV OM RELIGIøS utdannelse tradisjonelt har vært forbeholdt menn, har det etter revolusjonen vært en formidabel økning i antall kvinner som ønsker å ta fatt på teologistudiet. Det er bevisste kvinner med ulik bakgrunn som søker seg til de teologiske miljøene i Qom, Mashhad og Teheran, hvor det er høyskolenes moralske og faglige kriterier som er av avgjørende betyding for deres valg av studiested. For disse kvinnene er det religiøse studiet en metode som hjelper dem å kjenne sine rettigheter og sitt sosiale ansvar som muslimer. Islam er for dem individets og samfunnets løsning, og av den grunn føler de seg forpliktet til å støtte opp om en videre islamisering av den iranske republikk. Gjennom sin kunnskap er de i stand til å sette premisser for hvilke rettigheter det islamske prosjektet bør innebære for kvinner. Det er derfor interes- sant å se nærmere på hvorvidt kvinner i teologiske institusjoner mener kvinner kan tildeles status som ayatollah, og slik fungere som religiøse ledere ${ }^{\mathrm{I}}$. Det vil i denne artikkelen primært legges vekt på hvilket standpunkt kvinnelige teologisstudenter tar til dette sensitive spørsmålet. Er det slik at kvinner som har valg å studere ved de konservative miljøene i Mashhad og Qom har et konservativt syn på kvinnerollen? Før det ses nærmere på dette, vil det kort bli gjort rede for hva som ligger til grunn for ayatollah-embetet.

\section{Tro og tradisjon}

Ayatollah-tittelen er relativ ny av dato. Det var først på begynnelsen av I9oo-tallet at den sporadisk ble tatt i bruk, trolig i et forsøk på å styrke geistlighetens posisjon under tidligere makthavere. Det er rettslærde menn med tittelen mujtahid som har lykkes i å samle en krets av tilhengere, som av sin læremester kan tildeles ayatollah-tittelen. En mujtahid er en person som har fullført studiene i islamsk rettsvitenskap ved et av de berømte lærestedene $i$ Qom, Mashhad eller Najaf i Irak. Ved å beherske Koranen, tradisjonen og loven, har den rettslærde rett til å foreta selvstendige tolkninger (ijtihad) i spørsmål om islamsk tro og praksis. Som rettsprinsipp symboliserer ijtihad ikke bare religiøs innsikt, men også evne til logisk og rasjonell tenkning.

For å skille de mer prominente ayatollahene fra de andre, skjer en ny seleksjon. Ayatollaher med lang erfaring og høy anseelse kan av geistligheten utpekes til "modell til etterligning" (marja al-taqlid) og få tittelen stor-ayatollah (ayatollah aluzma). Dette er det religiøse samfunnets høyeste autoritet, en autoritet som hviler på 
både vitenskaplig kompetanse og antall tilhengere. Anerkjennelse og innflytelse som rettslærd er avhengig av personlig evne til å samle en krets av trofaste tilhengere. Enhver shia-muslim som ikke er spesialist på Loven er pålagt å følge en stor-ayatollah $i$ alle rettslige og religiøse anliggender. Selv om det er mulig for de troende å skifte "forbilde", bidrar statusen som "forbilde" til at de rettslærde har en særdeles serk makt og innflytelse.

De rettslærdes oppgave er å sørge for at folk og samfunn etterlever Guds lov, til den dag da Den skjulte imam vender tilbake for å opprette et rettferdig rike. Hvorvidt de rettslærde er i stand til å opprette en legitim stat under imamens fravæ, har vær gjenstand for debatt. Med opprettelsen av Den islamske republikk ble forøvrig de rettslærdes posisjon formelt befestet $\mathrm{i}$ den iranske grunnlov av 1979, hvor det lyder at de skal inneha sentrale statlige posisjoner i den islamske staten som er forankret i shari' a. ${ }^{2}$

\section{Tillater islam kvinnelige ledere?}

Selv om tilgangen til religiøs skolering er forbedret for kvinner, er muligheten for faglig fordypning og ervervelse av geistlige embeter fremdeles svært begrenset. Spesielt er det vanskelig for kvinner å fordype seg i fiqh (islamsk rettspraksis), fordi islamske embeter er forbeholdt menn. På samme måte som med ayatollah-embetet, kan ikke kvinner utpekes til "modell til etterligning”. Kvinner som åndelige ledere strider nemlig mot den tradisjonelle tolkningen om at menn ikke må underordne seg og følge kvinners direktiver. Det er sure 4, vers 34 i Koranen som ligger til grunn for denne regelen og som slår fast mannens autoritet. Her lyder det at "menn er kvinners formyndere på grunn av det som Gud har utstyrt dere med fremfor andre". Ved å vise til at Gud har skapt mann og kvinne med forskjellige egenskaper, argumenteres det fra tradisjonelt hold for at kvinner og menn har ulike ans-

\section{Kvinner som åndelige ledere strider} mot den tradisjonelle tolkningen om at menn ikke må underordne seg.

var og rettigheter. Kvinner er skapt til å føde og fostre barn og er av den grunn gitt en emosjonell natur, en egenskap som hemmer den rasjonelle tanke. Det er derfor ikke "naturlig" å skulle referere til kvinner i saker som har å gjøre med islamsk tro og praksis. Retten til å være forbilde er med andre ord forbeholdt menn, mens kvinners religiøse virke i stor grad er konsentrert om områder som undervisning og islamsk propaganda ${ }^{3}$.

Det finnes derimot andre tolkinger av koranverset. De mest radikale fremhever at formynderrollen er knyttet til mannens forsørgeransvar. Når kvinner også bidrar økonomisk til familien, hevdes det at grunnlaget for den tradisjonelle forståelsen faller bort. I stedet fremheves koranvers som oppfordrer til gjensidig ansvar mellom kvinner og menn, som sure 9, vers 7I. Her lyder det at: "De troende, menn og kvinner, har venners ansvar for hverandre."

Selv om det for troende er forbudt å referere til kvinner i saker som angår lovens forordringer, er rettslærde kvinner pålagt å følge sine egne tolkninger. Dersom en mannlig rettslærd går god for noen av deres 
tolkninger, ved selv å etterprøve dem, kan han legge dem til grunn for sin juridiske erklæring (fatwa). Innenfor det religiøse systemet kommer det slik til uttrykk selvmotsigelser som er gjenstand for kritikk. Det stilles spørsmålstegn til hvorfor rettslærde kvinner er pålagt å følge sine egne tolkninger, når de hevder å være uegnet til å veilede andre. Er ikke anerkjennelse av kvinners juridiske slutninger et tilstrekkelig bevis på at kvinner rasjonelt sett er likestilt med menn, og derfor egner seg som ayatollah?

Elham, som studerer islamsk rettsvitenskap ved Det teologiske fakultet ved Universitetet i Teheran, stiller seg positivt til kvinnelige ayatollaher. Etter at hennes forelesning i islamsk rettsvitenskap er avsluttet, blir vi sittende og prate sammen. Noen av hennes kvinnelige medstudenter tar også del i samtalen. Når jeg spør Elham hvordan det er å studere fiqh ved fakultetet, forteller hun at det er vanskelig å kombinere morsrollen med studiene. I likhet med denne dagen har hun ofte med seg den nyfødte datteren til forelesningene. I fanget til Elham står den vesle jentas lyse klær i sterk kontrast til morens sorte drakt. Elham forteller meg at kvinner evner å foreta rasjonelle tolkninger av shari' a på lik linje med menn. Hun oppfatter likevel menn som bedre egnet som rettsdommere enn kvinner, fordi de psykisk sett står sterkere til å håndtere de følelsesmessige påkjenninger som kan oppstå i et rettslokale. Ayatollah-embetet krever ikke samme psykisk styrke, og kvinner egner seg derfor bedre som ayatollah enn som dommere. Det er altså ikke kvinners dømmekraft Elham betviler. Hennes syn er noe utradisjonelt, da kvinner i dag kan fungere som dommere, mens status som ayatollah fremdeles er forbeholdt menn.

Grad av sensitivitet er altså av avgjørende betydning i spørsmålet om kvinnelige ayatollaher. Dette skyldes at fornuften (aql) i shia-islamsk rettstenkning representerer en sikker kunnskapskilde. Rasjonalitet brukes både til å utlede det religiøse innholdet og demonstrere lovens gyldighet. I motsetning til menn, er kvinners vurderinger subjektive fordi deres sterke følelser "blinder" dem. Dette mener Maryam ikke stemmer. Hun studerer islamsk rettsvitenskap i byen Mashhad. Hun forteller at siden hun selv ønsker å bli ayatollah, har hun analysert problemstillingen. Hun har kommet frem til at elementer som forståelse og erkjennelse er avgjørende for riktige rettsavgjørelser, og at kvinner - uavhengig av deres emosjonelle natur - tilfredsstiller disse kravene.

Maryam har bedt meg med til sitt hjem i Mashhad. Siden det bare er oss kvinner og barna som er samlet i hjemmet, lar Maryam hijaben ligge. Mens Maryams barn er opptatt av å se på tegnefilm, setter vi oss ned ved de store persiske veggputene i stua. På gulvet foran oss er det satt fram nytraktet te og smakfulle frukter. Hun forteller meg at det ikke er uvanlig at kvinner tar fatt på teologistudiet sammen med ektefellen, men at situasjonen for hennes del er noe annerledes. Mens hun fordyper seg i islamsk rettsvitenskap, har ektefellen valgt matematikk som sitt fagfelt. I så måte er Maryams samliv noe utradisjonelt, fordi det $i$ en geistlig familie vanligvis er ektemannen som representerer teologisk kunnskap, og ikke kvinnen.

I ti år har Maryam studert islamsk rettsvitenskap ved Mashhads største religiøse lærested for kvinner, Maktab-e Narges. Det er en økende interesse blant 
kvinner for å studere fiqh, og i likhet med Maryam ønsker flere å gå videre til det høyeste og avsluttende nivået, dars al-kharij. På dette nivået studerer man "utenfor pensum” og løser hypotetiske juridiske problemstillinger i samråd med en ayatollah. Gjennom muntlig deltakelse søker studentene å teste sine retoriske ferdigheter og sin religiøse kunnskap. Fullført studium fører frem til en kompetanseerklæring som bekrefter at den rettslærde kan bruke skjønn i spørsmål vedrørende islamsk tro og praksis. I mangel på kvinnelige lærere på dars al-kharij, forsøker kvinner som Maryam å få innpass ved de mannlige studiestedene med løfte om å være "tause og usynlige tilskuere” i undervisningen. På grunn av sitt ønske om å fordype seg $\mathrm{i}$ rettsvitenskap, er de med andre ord villig til å gi avkall på den muntlige deltakelsen som er så viktig på dette nivået. Deres forslag har ikke ført frem. De nektes adgang med begrunnelsen om at kvinner og menn må holdes atskilt.

Ved fakultetet til Elham, så det ut til at kvinner lettere slapp til i studiet av islamsk rettsvitenskap. I stedet for å holdes atskilt, studerer kvinner og menn her sammen. Studiet er også åpent for ikke-muslimer. For øvrig er det ved fakultetet merkbare forskjeller i kvinnenes ytre fremtoning. I likhet med sine kvinnelige kollegaer i Mashhad og Qom er også kvinnene ved Det teologiske fakultet pålagt å bære chador ${ }^{5}$. I Iran fremheves chadoren som den form for hijab som best kan beskytte kvinnens dyd, hvor sort er den frommeste fargen å velge. Til tross for nærææ av sine mannlige medstudenter unnlot flere av kvinnene at chadoren dekket til ansiktet og deler av, slik deres kvinnelige kollegaer i Qom og Mashhad passet godt på å gjøre. I stedet bar kvinnene chadoren åpen ved å la den hvile på hodet uten å holde grep om den rundt ansiktet, noe som førte til at fargerike maqneer ${ }^{6}$ og damefrakker kom til syne. Chador er et tildels tungt plagg å bære, og fordi den ofte holdes fast til hodet ved hjelp av en smal strikk, kan man oppleve at den blir hengende skjevt og subbe i bakken. Det var ikke uvanlig å se kvinner i fakultetets korridorer forsøke å rette på chadoren, ved å ta den av seg, for så å legge den riktig om hodet, slik at den foldet seg korrekt fra hodet og ned til anklene. At deres mannlige kollegaer i dette øyeblikket så dem uten chador, så ikke ut til å til å spille noen rolle for dem. Deres oppførsel antyder at chadoren er en nødvendig formalitet de som studenter er pålagt av fakultetet å overholde, snarere enn et utrykk for ideologisk overbevisning.

Selv om Det teologiske fakultetet kan virke mer åpent for kvinner, er Fru Niik et eksempel på at de konservative miljøenes krav om segregasjon mellom kjønnene også åpner opp for kvinners innflytelse. Fru Niik er rektor for den kvinnelige teologihøyskolen Nosrat i Mashhad, og er en meget from og respektert kvinne. Som mor kommer hensynet til familien først og selv om stillingen hennes også krever sitt, evner hun likevel å tilbringe hele natten $\mathrm{i}$ bønn ved imam Rezaz grav en gang i uken. Fru Niik inviterer meg inn til høyskolen for samtale. Etter at en av de mannlige ansatte har servert oss te, tar hun de sorte hanskene av seg. Hun folder den sorte chadoren om midjen og lar den falle fra hodet, slik at den blir liggende og hvile på skuldrene. Under den sorte chadoren har hun foruten den sorte frakken, to stykker sorte maqneer tredd over hodet. Den ene av dem tar hun av, men beholder den andre 
på. Denne har to ekstra stoffstykker i snittet rundt hodet. Det ene stoffstykke dekker panne, mens det andre dekker haken, slik at det bare er en liten del av ansiktet hennes som synes. Slik demonstrerer hun at tildekning også skal praktiseres i møte med en vestlig ikke-muslimsk kvinne, en praksis som er grunnet på en meget konservativ tolkning av Koranen.

Fru Niiks syn på kvinnelige ayatollaher er i tråd med teokratiets offisielle ideologi. Hun gir uttrykk for at hun oppfatter shari' a som helt klar på dette punktet. For henne er nytolkninger av ayatollah-embetet et ikke-diskuterbart tema. Med sin høye utdannelse og innflytelsesrike samfunnsposisjon fremstår likevel Fru Niik som en moderne kvinne, som i kraft av sin posisjon oppfordrer kvinner til faglig og sosial utfoldelse.

I motsetning til Fru Niik, tolker ikke Zeinab ayatollah-embetet som et spørsmål om kjønn, men hvorvidt man oppfyller moralske og faglige kriterier. Hun studerer ved den konservative høyskolen Jame' at alZahra i Qom. Høyskolen er drevet av og for kvinner og er trolig det mest kjente teologiske studiestedet for kvinner i Iran. Her studerer omlag I200 kvinner fra en rekke land. Høyskolen, som er omringet av en høy mur, følger strenge moralske påbud. Menn har ingen adgang, og som vestlig ikke-muslimsk kvinne er det vanskelig å få slippe inn. Jeg er heldig. Jeg har de riktige kontaktene og får komme inn gjennom en av høyskolens sidedører. Innenfor blir jeg møtt av sortkledde kvinner, på vei til eller fra høyskolens undervisningslokaler eller internat.

Zeinabs studiested står innenfor rammen tradisjonell rettsvitenskap (fiqh-e sunnati) som vanligvis benekter at islam tillater kvinnelige ayatollaher. Zeinab ser derimot ut til å representere nye tanker om ayatollah-embetet. Med et sterkt engasjement forklarer hun meg at så lenge kvinner respekterer og overholder de islamske normer, legger islam ingen hindringer i veien for kvinner. "Dersom man som kvinne oppfyller de faglige og moralske kriterier som ayatollah-embetet gjør krav på, ja, så hvorfor ikke?" Som forkjemper for kvinners rettigheter mener hun likevel det er langt viktigere saker som bør prioriteres enn kvinnelige ayatollaher.

I fjorten år har Zeinab fordypet seg i tolkninger av Koranen (tafsir). At hun selv kan tolke Koranen, stiller henne i en særdeles sterk posisjon som kvinne. Slik er hun ikke blott passiv mottaker for de tolkninger menn har autoritet på, men kan selv vurdere hvorvidt tolkningene er i overensstemmelse med Guds ord. Slik er Gud den primære autoritet, ikke menn. I kraft av å

“Dersom man som kvinne oppfyller kravene som ayatollah-embetet gjør krav på, ja, så hvorfor ikke?"

være erfaren student underviser Zeinab de yngre studentene ved Jame' at al-Zahra. Som lærerinne understreker hun betydningen av at kvinnene gjennom sitt selvstendige arbeid lærer å finne fram til kildene for på egen hånd å tolke den hellige skrift og tradisjon. Hun synes det også er viktig at lærere og studenter diskuterer med hverandre, slik at studentene får testet ut sin kunnskap og retoriske evner.

Når kvinner som Zeinab trer frem på den religiøse arena, bidrar deres deltakelse 
til at kvinnespørsmålet settes på dagsorden innenfor et system som tradisjonelt har vær forbeholdt menn. I et samfunn hvor stadig flere kvinner de siste tjue årene tar høyere utdannelse, og hvor kvinner i økende grad trer frem som politikere, leger og rektorer og slik markerer seg som rasjonelle individer, medfører dette at troverdigheten til tradisjonelle tolkninger svekkes. Den tradisjonelle oppfatningen av kvinnen stemmer ikke med det man erfarer i virkeligheten. Det er på grunnlag av denne konflikten de rettslærdes tolkninger kritiseres og at det gjøres nye tokninger av shari' a.

Krav om nytolkninger har ført fram. Fra I992 har kvinner kunnet rådgi mannlige dommere i teokratiets rettssystem og i I998 fikk Iran sin første kvinnelige dommer etter revolusjonen . Kvinners virke i det religiøse rettsystemet er likevel særdeles begrenset. I straffespørsmål er de ikke engang tillatt adgang til rettslokalet og i spørsmål relatert til familierett kan de ikke avgi dom. I likhet med kvinnelige ayatollaher er spørsmålet om kvinnelige dommere fremdeles betent, fordi det står i strid til den tradisjonelle tolkningen om at menn ikke må underordne seg og følge kvinners direktiver.

\section{Nytolkninger av rettspraksisen?}

Gjennom sin kunnskap kan kvinner ta stilling til hvorvidt det er nødvendig med en mer progressiv lovgivning, slik at juridiske tolkninger av shari' a i større grad samsvarer med samtiden. Det er et spørsmål om hvorvidt rettsvitenskapen skal være dynamisk (puya) eller tradisjonell (sunnati). Dette er et komplisert spørsmål som det her ikke er rom for å redegjøre for i detalj. Kort fortalt mener tilhengerne av fiqh-e puya at shari' a er et langt mer fleksibelt begrep enn det de rettslærde tradisjonelt forfekter. De hevder at rettsvitenskapen har stoppet opp i sin utvikling og derfor ikke evner å gi svar på de politiske, sosiale og religiøse utfordringer det iranske samfunnet i dag står ovenfor. Det trengs nytolkninger for å kunne gi islamske svar på disse utfordringene. Korantolkninger

Gjennom sin kunnskap kan kvinner ta stilling til hvorvidt det er nødvendig med en mer progressiv lovgivning.

hevdes å kunne gi ny forståelse av Koranen, og fremfor en "etterligning” (taqlid) av tidligere rettsavgjørelser trekkes ijtihad frem som det viktigste prinsippet for ny rettsforståelse. Prinsippet om taqlid ligger sterkt til grunn for det religiøse systemet og kan se ut til å vanskeliggjøre en reform av rettsvitenskapen, da konservative krefter oppfatter endrede rettsoppfatninger som en trussel mot islam. Av den grunn har representanter for en progressiv lovgivning vært gjenstand for aggressive angrep fra konservative miljøer.

Fra tradisjonelt hold argumenteres det for at dagens rettsvitenskap evner å gi svar på de utfordringer det moderne samfunnet står ovenfor. Det gis støtte til påstanden ved å vise til hvilken sosiopolitisk betydning ulike juridiske erklæringer har hatt gjennom historien. Et eksempel som stadig fremheves er hvordan Miza Hasan Shirazi (d.I9I4) erklærte boikott av den britiske tobakksindustrien. Denne fatwaen betraktes som en forløper til den konstitusjonelle revolusjon i Iran fra I905 til I9II. Fatwaen 
vakte internasjonal oppsikt, fordi den markerte begynnelsen på en massepolitisk vekkelse mot vestlig dominans. Både Elham og Maryam trekker fram dette eksempelet for å demonstrere hvordan rettsvitenskapen i shia-islam er dynamisk av natur. Slik blir deres synspunkter stående innenfor rammen av fiqh-e puya. For dem er ikke islamsk rettvitenskap uforenlig med sosial utvikling.

Med et ønske om å videreføre det shiaislamske prosjektet mener Zeinab det er nødvendig å forene religiøs kunnskap med moderne fagdisipliner som blant annet sosiologi og økonomi. Hun betegner denne foreningen som "Den nye teologien” og argumenterer for sitt syn ved å vise til hvordan islam oppfordrer folk til å søke kunnskap som kan tjene til en bedre forståelse av menneske og samfunn. Hennes syn er helt i tråd med flere av reformistene i det teologiske miljøet. Tanken er at man trenger ny kunnskap, dersom man skal kunne finne islamske løsninger på moderne samfunnsproblemer. Konservative krefter hevder derimot at utvidet fagtilbud vil føre til begrenset teologisk kunnskap, og slik svekke studentens religiøse innsikt. Diskusjonen om fornyelse både i forhold til religiøse skrifttolkninger og det religiøse utdanningssystemet, oppfattes som like politisk sensitiv som spørsmål om kvinnelige ayatollaher.

\section{Konklusjon}

Som tilhenger av kvinnelige ayatollaher og fiqh-e puya, ser Zeinab ut til å støtte opp om moderne islamske ideer som hennes høyskole, Jame' at al-Zahra, ikke kan sies å representere. I likehet med Maryam, er Zeinab et eksempel på at kvinner som søker seg til konservative teologiske miljøer, ikke nødvendigvis forfekter et konservativt kvinnesyn. Dette viser at reformtanker knyttet til ayatollah-embetet ikke bare får støtte av kvinner som Elham fra liberale teologimiljøer. Zeinab, Elham og Maryam, som representerer det teologiske miljøet i henholdsvis Qom, Teheran og Mashhad, er ikke bare lojale kvinner som passivt tilpasser seg sosio-religiøse normer. De markerer seg som bevisste kvinner med et sterkt sosialt engasjement som maner frem religiøs nytenkning. For dem er en videre islamisering av Den islamske republikk ikke uforenlig med utvidede rettigheter for kvinner. At kvinner som dem deltar på den religiøse arena, kan muligens bidra til at kvinners juridiske rettigheter forbedres. I fremtiden vil man dermed kanskje kunne følge kvinnelige ayatollaher i spørsmål vedrørende islamsk tro og praksis.

\section{- $f \cdot$}

I Denne artikkelen bygger hovedsaklig på mitt feltarbeidsmateriale fra Iran, høsten 2000.

2 Schirazi, A. I997: «The Constitution of Iran. Politics and the State in the Islamic Republic», I.B.Taubris, London, New York

3 Pettersen, K. 200I: "Kvinner og religiøse embeter. En komparativ studie av kvinner som studerer shia-teologi i Iran", Hovedfagsoppgave i Religionshistorie, Univer$\mathrm{s}$ i Oslo.

4 I Koranen (33:53) kan man lese at hijab, som betyr forheng, innebar en visuell atskillelse mellom profetens koner og de mannlig besøkende.

5 Chador er en iransk kvinnedrakt som består av et heldekkende tøystykke.

6 Maqne er en hette som dekker skuldre og bryst og bæres sammen med damefrakken.

7 Mir-Hosseni, Z. 2000: «Islam and Gender. The religious Debate in Contemporary Iran», I.B.Taubris, London, New York. 